\title{
3: 52419049-52410067
}

National Cancer Institute

\section{Source}

National Cancer Institute. 3:52419049-52410067. NCI Thesaurus. Code C41748.

Physical location of BAP1_Gene 